\title{
ERYTHROCYTE METABOLISM. THE METABOLIC BEHAVIOR OF THE CHOLESTEROL OF HUMAN ERYTHROCYTES ${ }^{1}$
}

\author{
BY IRVING M. LONDON 2 AND HAIYIM SCHWARZ
}

\author{
(From the Department of Medicine, Columbia University, College of Physicians and Surgeons \\ and the Presbyterian Hospital, New York, N. Y.)
}

(Submitted for publication July 21, 1953 ; accepted August 11, 1953)

In the course of studies on the ageing process in the human erythrocyte, we have investigated the metabolic behavior of the cholesterol of the erythrocyte. This study was designed to determine whether the cholesterol of the human erythrocyte is in the dynamic state (2), or whether the cholesterol is incorporated into the newly formed erythrocyte and remains with the cell throughout the cell's life span, as does hemoglobin (3-6).

A previous study (7) has shown that the cholesterol of the plasma is in the dynamic state. The rate of entry of cholesterol into the plasma of the circulating blood was measured by determining the rate at which deuterium is incorporated into the cholesterol of the plasma when an elevated concentration of deuterium in the body water is maintained at a steady level by repeated administration of deuterium oxide. In the studies described in this report, the same technique has been employed and the concentrations of deuterium in the cholesterol of the erythrocytes and of the plasma have been compared. Since the cholesterol of the plasma is in the dynamic state, the finding of a similar rate of turnover and a similar pattern of concentrations of deuterium in the cholesterol of the erythrocytes would favor the conclusion that the cholesterol of the erythrocytes is also in the dynamic state.

The subjects of this study were a patient with the nephrotic syndrome and a patient with xanthomatosis tuberosum multiplex. A discussion of the mechanisms involved in the maintenance of hypercholesterolemia in these conditions is beyond

\footnotetext{
1 This work was presented in part before the American Society for Clinical Investigation at Atlantic City, May 1951 (1). The work was supported by a grant from the American Cancer Society on the recommendation of the Committee on Growth of the National Research Council and by a grant from the Office of Naval Research.

2 Part of this work was performed during the tenure of a Welch Fellowship in Internal Medicine of the National Research Council.
}

the scope of this paper and will not be presented here.

\section{MATERIAL AND METHODS}

Subjects: 1) F. G., a 36 year old Negro woman, was studied during the nephrotic phase of chronic glomerulonephritis. Pertinent laboratory data included a red blood cell count of 3.5 million per cubic millimeter, hemoglobin of $10.0 \mathrm{Gm}$. per $100 \mathrm{ml}$. of blood, and venous hematocrit of 33 per cent; plasma total cholesterol $836 \mathrm{mg}$. per cent with 70 per cent of the total cholesterol esterified; erythrocyte total cholesterol $146 \mathrm{mg}$. per cent with 11 per cent of the total in the ester form and 89 per cent in the form of free cholesterol.

2) M. T., a 21 year old white woman with xanthoma tuberosum multiplex, was essentially asymptomatic. Hematologic data included a red blood cell count of 4.2 million per cubic millimeter and a hemoglobin value of $13.0 \mathrm{Gm}$. per $100 \mathrm{ml}$. of blood. Plasma total cholesterol was found to range between $500 \mathrm{mg}$. per cent and $660 \mathrm{mg}$. per cent with 71 to 75 per cent of the total esterified. Erythrocyte total cholesterol was $132 \mathrm{mg}$. per cent with 95 per cent of the total in the form of free cholesterol and 5 per cent in ester form.

Administration of deuterium oxide: 1) Subject F. G. drank $1000 \mathrm{ml}$. of 50 per cent $\mathrm{D}_{2} \mathrm{O}$ in four divided doses on the first day of the experiment and then received 60 to $65 \mathrm{ml}$. per day of approximately 30 per cent $\mathrm{D}_{2} \mathrm{O}$ for the next 112 days. On 11 occasions the daily dose was doubled in order to maintain the body water concentration of deuterium at a steady level. The concentration of deuterium in the body water was measured by determining the concentration of deuterium in the water of the urine.

2) Subject M. T. drank $666 \mathrm{ml}$. of 50 per cent $\mathrm{D}_{2} \mathrm{O}$ in three divided doses on the first day of the experiment and 50 to $60 \mathrm{ml}$. of 50 per cent $\mathrm{D}_{2} \mathrm{O}$ daily for the duration of the study.

Isolation and quantitative determination of cholesterol: The erythrocytes were washed three times with 0.9 per cent solution of sodium chloride. The buffy coat of leucocytes was removed and discarded. Total cholesterol was isolated as the digitonide from the unsaponifiable fractions of erythrocytes and of plasma and was then recovered from the digitonide according to the method of Schönheimer and Dam (8). Melting point determinations were used as an index of purity.

Quantitative determinations of cholesterol were per- 
formed according to the Sperry-Schoenheimer method $(9,10) .^{3}$

Measurement of concentration of deuterium: The concentration of deuterium in the hydrogen derived from the cholesterol was determined according to the procedure of Graff and Rittenberg (11).*

Synthesis of cholesterol in vitro: Two hundred and seventy $\mathrm{ml}$. of blood were drawn from a normal man, the plasma and buffy coat were removed by centrifugation, the erythrocytes were suspended in 0.9 per cent sodium chloride solution, the suspension was centrifuged once, and the saline and the remaining buffy coat were discarded. The erythrocytes were suspended in saline to make a total volume of $280 \mathrm{ml}$. Two hundred $\mathrm{mg}$. of $1-\mathrm{C}^{\mathbf{1 4}}$ sodium acetate, $\mathrm{CH}_{8} \mathrm{C}^{14} \mathrm{OONa} \cdot 3 \mathrm{H}_{2} \mathrm{O}$, with a specific activity of 0.8 millicuries per millimole, was added to the cell-saline suspension. Penicillin and streptomycin were added to inhibit bacterial growth. The suspension was incubated for 25 hours with constant gentle shaking in air at $38^{\circ} \mathrm{C}$.

\section{RESULTS AND DISCUSSION}

The concentrations of deuterium in the cholesterol of the plasma and of the erythrocytes of both subjects are plotted in Figures 1 and 2. In each case, the rise in the concentration of deuterium in the cholesterol of the erythrocytes is similar to its rise in the cholesterol of the plasma. Since the cholesterol of the plasma is in the dynamic state, a similar rate of turnover in the cholesterol of the erythrocytes favors the conclusion that the cholesterol of the erythrocytes is also in the dynamic state. There are two possible mechanisms whereby the cholesterol of the erythrocyte could exist in a dynamic state: the first would require the synthesis of cholesterol by the circulating erythrocyte for replacement of cholesterol which has disappeared from the erythrocyte; the second would entail the replacement of the cholesterol of the erythrocyte by cholesterol from the plasma.

The first possibility, synthesis by the erythrocyte, was investigated by determining the capacity of mature human erythrocytes to synthesize cholesterol in vitro, as measured by the $\mathrm{C}^{14}$ concentration in the cholesterol of erythrocytes incubated with 1-C $\mathrm{C}^{14}$-sodium acetate $\left(\mathrm{CH}_{3} \mathrm{C}^{14} \mathrm{OONa}\right)$. The results of this experiment are presented in Table I.

That this synthesis of cholesterol by erythrocytes

$3 \mathrm{We}$ are indebted for these determinations to $\mathbf{M r}$. $\mathbf{M}$. L. Webb, in the laboratory of Dr. Warren M. Sperry, and to Miss Anne Richards, in the laboratory of Dr. Kenneth B. Turner.

4 Analyses in the mass spectrometer were kindly performed by Mr. Irving Sucher. in vitro is relatively insignificant can better be appreciated by comparison of these results with the in vitro synthesis of cholesterol in rat liver. On incubation of $60 \mathrm{Gm}$. of rat liver slices with 0.15 millicuries (25 mg.) of $\mathrm{CH}_{3} \mathrm{C}^{14} \mathrm{OONa} \cdot 3 \mathrm{H}_{2} \mathrm{O}$ for 3.5 hours, 7 per cent of the $\mathrm{C}^{14}$ labeled sodium acetate was converted to cholesterol. We recognize that it may be hazardous to conclude, on the basis of in vitro studies, that the mature human erythrocyte in vivo possesses only a very limited capacity to synthesize cholesterol. The contrast, however, between the active turnover of cholesterol of the erythrocyte and the very low rate of synthesis of cholesterol by the erythrocyte in vitro is sufficiently marked to favor the view that the existence of the cholesterol of the erythrocyte in the dynamic state is due to a process other than synthesis of cholesterol by the erythrocyte itself. The conclusion which is indicated by these findings is that the cholesterol of the erythrocyte is in dynamic exchange with the cholesterol of the plasma.

This conclusion is in agreement with studies performed simultaneously and independently in other laboratories. Determinations of $\mathrm{C}^{\mathbf{1 4}}$ activity in the cholesterol of a rabbit's erythrocytes after the administration of $\mathrm{CH}_{3} \mathrm{C}^{14} \mathrm{OONa}$ indicated that the cholesterol of the erythrocytes is in the dynamic state (12). Studies in vitro of dog erythrocytes and plasma have shown a rapid equilibration of the cholesterol of the erythrocytes with the free cholesterol of the plasma $(13,14)$. The administration of tritium $\left(\mathrm{H}^{3}\right)$ labeled cholesterol (15) or of $C^{14}$ labeled cholesterol (16) to man has revealed equilibration of cholesterol of the erythrocytes with the free cholesterol of the plasma.

Inasmuch as the major part of the cholesterol of erythrocytes is not esterified, equilibration of cholesterol of erythrocytes with the cholesterol of the plasma might be expected to involve the free cholesterol principally. It would seem likely, however, that the esterified cholesterol of the erythrocyte, which is present in low concentration, would also be in equilibrium with the esterified cholesterol of the plasma. The technique of $\mathrm{D}_{2} \mathrm{O}$ administration which was employed in this study would not be expected to reveal different isotope concentrations in free and esterified cholesterol of plasma. Consequently, the isotope concentrations in total cholesterol of erythrocytes and of plasma respectively were compared. 


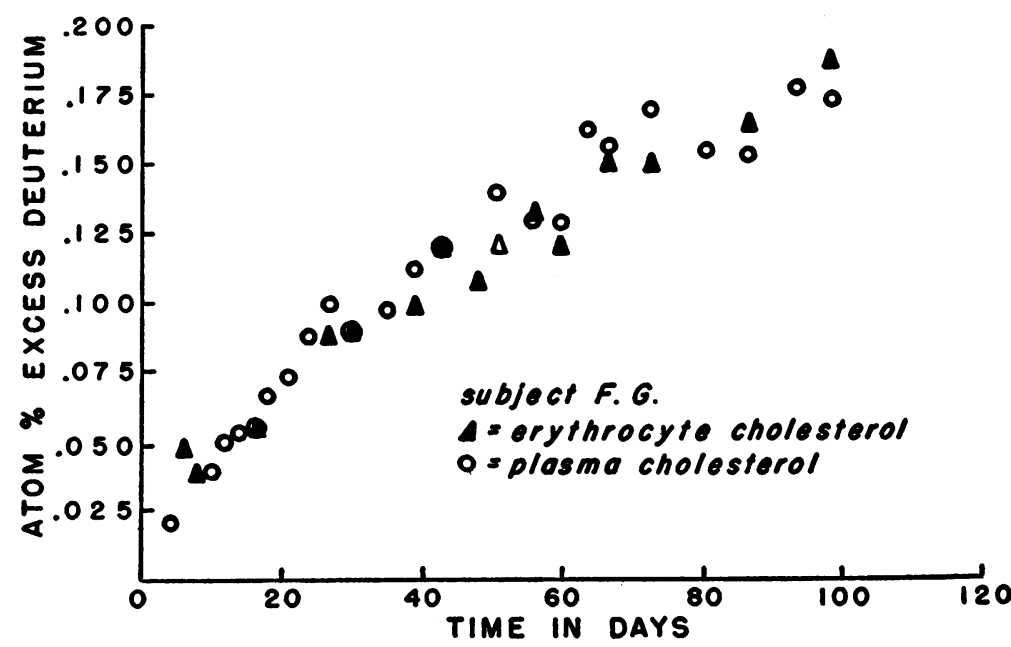

Fig. 1. Concentrations of Deuterium in the Total Cholesterol of Erythrocytes and of Plasma

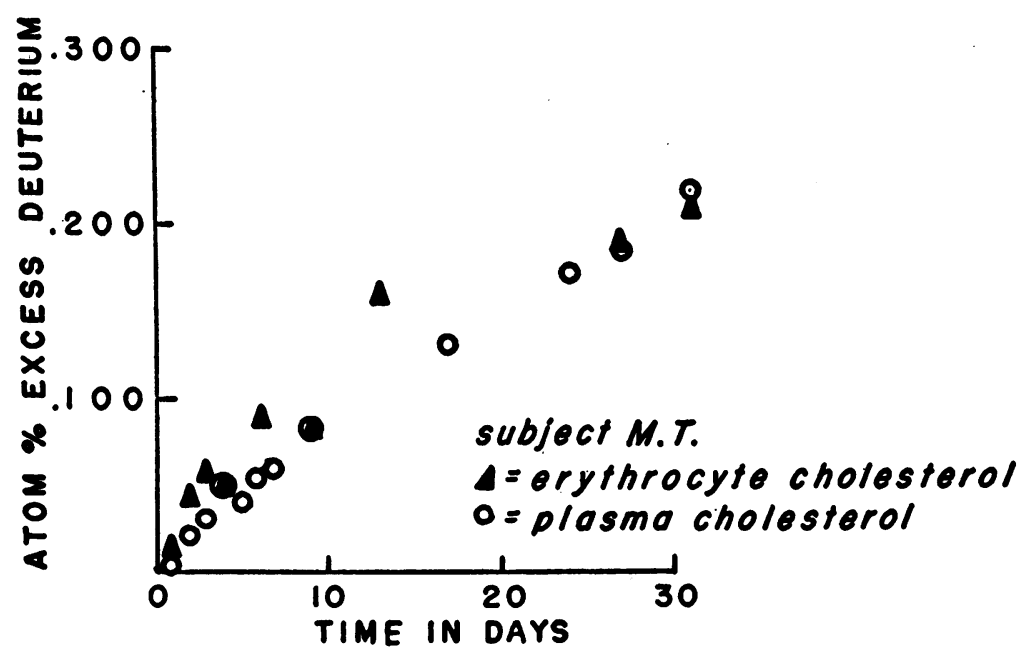

Fig. 2. Concentrations of Deuterium in the Total Cholesterol of Erythrocytes and of Plaska

The demonstration that the cholesterol of the mature human erythrocyte is renewed by exchange with cholesterol of the plasma is pertinent to the problem of ageing of the human erythrocyte. Several different techniques have established that the normal human erythrocyte survives for an average life span of about 120 days $(3,5,17,18)$. In the course of some of these and related studies (3-6, 18), it has been shown that the hemoglobin of the mature circulating erythrocyte is not in the dynamic state, but rather that it remains with the erythrocyte until the cell is destroyed. The determination of the metabolic behavior of hemoglobin and of other constituents of the human erythrocyte in normal and in pathologic states may provide some clues to an understanding of the ageing process in this cell. The behavior of constituents of the stroma of the erythrocyte may be particularly significant in determining the viability of the cell. The stroma is composed, at least in part, of lipoprotein complexes. The cholesterol of the erythrocyte is, most likely, bound to one or more proteins of the stroma and is probably part of one or more lipoprotein complexes. The evidence presented in this and other studies indicates that the cholesterol is metabolically labile. Earlier studies 
TABLE I

Synthesis of cholesterol in vitro by mature human erythrocytes

\begin{tabular}{|c|c|c|c|c|c|}
\hline $\begin{array}{l}\text { Weight } \\
\text { (wet) of } \\
\text { erythrocytes } \\
\text { incubated }\end{array}$ & $\begin{array}{c}\text { Amount of } \\
\mathrm{CH}_{3} \mathrm{C}_{14} \mathrm{OONa} \text {. } \\
3 \mathrm{H}_{2} \mathrm{O} \text { added }\end{array}$ & $\begin{array}{l}\text { Total C14 } \\
\text { activity } \\
\text { added }\end{array}$ & $\begin{array}{l}\text { Time of } \\
\text { incuba- } \\
\text { tion }\end{array}$ & $\begin{array}{l}\text { C14 activity* } \\
\text { of choles- } \\
\text { terol }\end{array}$ & $\begin{array}{l}\text { Per cent of } \\
\text { C14 acetate } \\
\text { converted to } \\
\text { cholesterol }\end{array}$ \\
\hline $\mathrm{Gm}$. & $m g$. & $\begin{array}{l}\text { milli- } \\
\text { curies }\end{array}$ & hours & c.p.m. & \\
\hline 120 & 200 & 1.2 & 25 & 21 & 0.0004 \\
\hline
\end{tabular}

* The $\mathrm{C}^{14}$ activity is expressed as counts per minute above background for an infinitely thick sample.

$(19,20)$ and findings in this laboratory on the metabolism of phospholipids in the erythrocytes of man (21) indicate a rapid turnover of total phospholipids, as well, in these cells. The metabolic behavior of the stroma proteins is not yet known but a preliminary report suggests that most of the proteins in the stroma of the rat erythrocytes are, once formed, as stable metabolically as hemoglobin (22).

It is tempting to speculate on the relevance of these observations to the mechanisms which are responsible for maintaining the viability of the cell, and, more particularly, for maintaining the integrity of the erythrocyte membrane. The maintenance of an intact membrane may require a continuing rapid exchange of cholesterol and other lipids with similar constituents in the plasma, and, at the same time, may require metabolic stability of some proteins of the stroma. It is possible that one or more proteins of the stroma are in the dynamic state, and the integrity of the cell structure may be dependent on a continued replacement of these proteins. In any case, the structure of the human erythrocyte appears to depend on the maintenance of some constituents in a dynamic state and of others in an unreactive or stable state. The death of the erythrocyte may result from loss of metabolic lability of some constituents or from loss of metabolic stability of others. Further definition of the metabolic behavior of various constituents in erythrocytes of different ages may provide illuminating information on the process of ageing in the human erythrocyte.

\section{SUM MARY}

In two human subjects, in whose body water an elevated concentration of deuterium was maintained by the administration of deuterium oxide, the rise in the concentration of deuterium in the cholesterol of the erythrocytes was similar to its rise in the cholesterol of the plasma. This finding and the demonstration of a relatively insignificant degree of synthesis of cholesterol by human erythrocytes in vitro favor the conclusion that the cholesterol of human erythrocytes is in dynamic exchange with the cholesterol of the plasma. The possible relevance of the metabolic lability of the cholesterol of erythrocytes to the problem of the ageing process in the human erythrocyte is indicated.

\section{REFERENCES}

1. London, I. M., Sabella, G. F., and Yamasaki, M. M., Studies on the metabolism of cholesterol in normal man and in the nephrotic syndrome. J. Clin. Invest., 1951, 30, 657.

2. Schoenheimer, R., The dynamic state of body constituents, ed. 2, Cambridge, Harvard University Press, 1946.

3. Shemin, D., and Rittenberg, D., The life span of the human red blood cell. J. Biol. Chem., 1946, 166, 627.

4. London, I. M., Shemin, D., West, R., and Rittenberg, $\mathrm{D}$., Heme synthesis and red blood cell dynamics in normal humans and in subjects with polycythemia vera, sickle-cell anemia, and pernicious anemia. J. Biol. Chem., 1949, 179, 463.

5. Jope, E. M., The disappearance of sulphemoglobin from the blood of TNT workers in relation to the dynamics of red cell destruction. Brit. J. Indust. Med., 1946, 3, 136.

6. Grinstein, M., Kamen, M. D., and Moore, C. V., The utilization of glycine in the biosynthesis of hemoglobin. J. Biol. Chem., 1949, 179, 359.

7. London, I. M., and Rittenberg, D., Deuterium studies in normal man. I. The rate of synthesis of serum cholesterol. II. The measurement of total body water and water absorption. J. Biol. Chem., 1950, 184, 687.

8. Schönheimer, R., und Dam, H., Utber die spaltbarkeit und löslichkeit von sterindigitoniden. Ztschr. f. physiol. Chem., 1933, 215, 59.

9. Schoenheimer, R., and Sperry, W. M., A micromethod for the determination of free and combined cholesterol. J. Biol. Chem., 1934, 106, 745. 
10. Sperry, W. M., and Webb, M., A revision of the Schoenheimer-Sperry method for cholesterol determination. J. Biol. Chem., 1950, 187, 97.

11. Graff, J., and Rittenberg, D., Microdetermination of deuterium in organic compounds. Analytical Chemistry, 1952, 24, 878.

12. Muir, H. M., Perrone, J. C., and Popják, G., Studies on the metabolism of the circulating erythrocyte in the rabbit. Biochem. J., 1951, 48, iv.

13. Gould, R. G., Lipid metabolism and atherosclerosis. Am. J. Med., 1951, 11, 209.

14. Hagerman, J. S., and Gould, R. G., The 'in vitro' interchange of cholesterol between plasma and red cells. Proc. Soc. Exper. Biol. \& Med., 1951, 78, 329.

15. Biggs, M. W., Kritchevsky, D., Colman, D., Gofman, J. W., Jones, H. B., Lindgren, F. T., Hyde, G., Lyon, G., and Lyon, T. P., Observations on the fate of ingested cholesterol in man. Circulation, 1952, $6,359$.
16. Hellman, L., Rosenfeld, R., Fukushima, D., Eidinoff, M., Brunschwig, A., and Gallagher, T., The major pathways of steroid metabolism in man. J. Clin. Invest., 1953, 32, 573.

17. Ashby, W., The span of life of the red blood cell. A résumé. Blood, 1948, 3, 486.

18. Finch, C. A., Wolff, J. A., Rath, C. E., and Fluharty, R. G., Iron metabolism. Erythrocyte iron turnover. J. Lab. \& Clin. Med., 1949, 34, 1480.

19. Hahn, L., and Hevesy, G., Phosphatide exchange between plasma and organs. Nature, 1939, 144, 204.

20. Zilversmit, D. B., Entenman, C., Fishler, M. C., and Chaikoff, I. L., The turnover rate of phospholipids in the plasma of the dog as measured with radioactive phosphorus. J. Gen. Physiol., 1943, 26, 333.

21. Unpublished data from this laboratory.

22. Muir, H. M., Neuberger, A., and Perrone, J. C., Further isotopic studies on haemoglobin formation in the rat and rabbit. Biochem. J., 1952, 52, 87. 